$\begin{array}{ll}\text { Dikumpulkan } & \text { : } 5 \text { Januari } 2018 \\ \text { Direvisi I } & : 16 \text { Januari } 2018 \\ \text { Direvisi II } & : \text { 19 Januari } 2018 \\ \text { Diterima } & : 8 \text { Februari } 2018 \\ \text { DOI } & : \text { https://doi.org/10.22146/jpt.35383 }\end{array}$

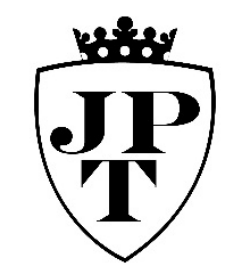

\title{
Strategi Komunikasi Pemasaran Wisata Nagari Koto Hilalang, Kabupaten Solok, Sumatera Barat
}

\author{
Yulia Sariwaty S', Dini Rahmawati ${ }^{2}$, Rina Dwi Handayani ${ }^{3}$, Yunika \\ Komalasari $^{4}$ \\ ${ }^{1}$ Universitas BSI-Bandung \\ yulia.ysy@bsi.ac.id \\ ${ }^{2}$ Universitas BSI-Bandung \\ dini.drm@bsi.ac.id \\ ${ }^{3}$ Akademi Pariwisata BSI-Bandung \\ rina.rdh@bsi.ac.id \\ ${ }^{4}$ Universitas BSI-Bandung \\ yunika.yui@bsi.ac.id
}

\begin{abstract}
Nagari Koto Hilalang is one of potential tourist villages in Solok Regency, West Sumatera Province. This area has beautiful landscape, traditional houses of Minang as heritage and hundreds years old of ancient artefacts as well as lifestyle of local community that still keeps socio-culture system and unique local wisdom. Those potentials have not been exploited, managed and developed to the maximum by the local government and community up to now. This research aimed to arrange the concept of marketing communication strategy for Nagari Koto Hilalang in Kubung Subdistrict, Solok Regency, West Sumatera Province to attract tourists' interest.
\end{abstract}

Keywords: Strategy, Communication, Marketing, Tourism 


\section{Pendahuluan}

Sumatera Barat merupakan salah satu provinsi dengan segudang potensi tujuan wisata yang menarik tidak hanya bagi wisatawan domestik maupun wisatawan mancanegara. Selain memiliki tempat-tempat bersejarah yang menarik untuk dikunjungi, adat istiadat masyarakatnya pun sangat kental dengan nilai-nilai historis yang unik untuk dipelajari. Upaya pengembangan objek wisata selain tempat-tempat yang mengandung sejarah (historis), pengembangan pariwisata terbaru dilakukan dengan menyiapkan potensipotensi kampung-kampung dan desadesa wisata.

Provinsi Sumatera Barat, sebenarnya memiliki banyak tempat-tempat destinasi pariwisata, terutama obyek wisata Alam, sejarah dan kebudayaan. Namun sayangnya, masih sedikit sekali yang terkenal di kalangan para wisatawan dan masih terfokus hanya pada obyek-obyek yang menjadi ikon daerah. Salah satu kawasan pedesaan yang asri dan masih mempertahankan nilai-nilai kebudayaan asli di Sumatera Barat adalah daerah Nagari Koto Hilalang di Kabupaten Solok.

Nagari Koto Hilalang merupakan salah satu daerah yang berada di Kecamatan Kubung, wilayah Kabupaten Solok, memiliki luas daerah $35,50 \mathrm{Km}^{2}$. Nagari Koto Hilalang memiliki batas administrasi sebagai berikut: Sebelah Utara berbatasan langsung dengan Kota Solok, sebelah Timur berbatasan dengan Nagari Selayo, sebelah Selatan dengan Nagari Gantung Ciri, dan di sebelah Barat dengan Kota Padang. Nagari Koto Hilalang terdiri dari 5 Jorong yaitu Jorong Dalam Nagari, Kapondong, Koto Tingga, Muaro Busuk, dan Jorong Aimpang Ampek. Penduduk Nagari Koto Hilalang berjumlah 3.016 jiwa, yang terdiri dari 1.447 jiwa laki-laki dan 1.569 jiwa perempuan. Jorong yang memiliki penduduk paling padat yaitu Jorong Dalam Nagari sebanyak 1.110 jiwa. Sedangkan jorong dengan jumlah penduduk paling kecil adalah Jorong Kapondong sebanyak 477 jiwa.

Desa wisata adalah sebuah kawasan pedesaan yang memiliki beberapa karakteristik khusus untuk menjadi daerah tujuan wisata. Ciri khas kawasan desa wisata, penduduknya masih memiliki tradisi dan budaya yang relatif masih asli. Selain itu, beberapa faktor pendukung seperti makanan khas, ssstem sosial dan sistem pertanian turut juga menjadi cirri unik yang mewarnai kondisi kawasan desa wisata. Di luar faktor-faktor tersebut, alam dan lingkungan yang masih asli dan terjaga merupakan salah satu faktor terpenting dari sebuah kawasan tujuan wisata.

Keberadaan desa wisata sebagai asset dan sumber perekonomian masih perlu diasah pemanfaatannya, salah satunya melalui pelatihan oleh pemerintah maupun swasta guna menciptakan kesejahteraan masyarakat desa wisata, agar mampu menjadi andalan pariwisata daerah. Pada umumnya desa wisata dikelola oleh warga setempat dengan suasana yang masih alami dan cenderung disukai oleh wisatawan.

Meskipun desa wisata dapat dikatakan sebagai model pariwisata unik dan dapat dikategorikan sebagai konsep tujuan wisata baru, kondisinya masih membutuhkan peran aktif dan kreatif dari pemerintah daerah dan masyarakat guna mengoptimalisasikan potensipotensi wisata lainnya yang dimiliki, karena desa wisata termasuk dalam wisata minat khusus dimana wisatawan dapat mempelajari berbagai hal yang telah menjadi cirri khas dari sistem sosial budaya masyarakat setempat.

Adapun rumusan masalah dalam penelitian ini adalah: 
1. Apa saja Faktor Pendukung Penyusunan Strategi Komunikasi Pemasaran terpadu Desa Wisata Nagari Koto Hilalang di Kabupaten Solok Provinsi Sumatera Barat?

2. Bagaimana strategi komunikasi pemasaran terpadu Desa Wisata Nagari Koto Hilalang di Kabupaten Solok Provinsi Sumatera Barat dalam menarik minat kunjungan wisatawan?

\section{A. Strategi}

Menurut Jack Trout dalam bukunya Trout On Strategy, strategi adalah bagaimana bertahan hidup dalam dunia kompetitif, bagaiaman membuuat persepsi baik di benak konsumen, menjadi berbeda, mengenali kekuatan dan kelemahan pesaing, menjadi spesialisasi, menguasai satu kata yang sederhana di kepala pemimpin yang memberi arah dan memahami realitas pasar dengan menjadi yang pertama daripada menjadi yang lebih baik. (Suyanto, 2007:16)

Berdasarkan pendapat Stoner, Freeman, dan Gilbert Jr., konsep strategi dapat didefinisikan berdasarkan dua perspektif yang berbeda, yaitu:

1) Perspektif apa yang ingin organisasi lakukan (intends to do), strategi dapat didefinisikan sebagai program untuk menentukan dan mencapai tujuan organisasi dan mengimplementasikan misinya. Makna yang terkandung dalam strategi ini adalah bahwa manajer memainkan peranan yang aktif, sadar dan rasional dalam merumuskan strategi organisasi.

2) Perspektif apa yang organisasi akhirnya lakukan (eventually does), strategi didefinisikan sebagai pola tanggapan atau respon organisasi terhadap lingkungannya sepanjang waktu.
Pandangan tersebut diterapkan bagi para manajer yang bersifat reaktif, yaitu hanya menanggapi dan menyesuaikan diri terhadap lingkungan secara pasif manakala dibutuhkan. (Tjiptono, 2007:3) Secara eksplisit, strategi merupakan kunci keberhasilan dalam menghadapi perubahan lingkungan bisnis. Strategi memberikan kesatuan arah bagi semua anggota organisasi. Bila konsep strategi tidak jelas, maka keputusan yang diambil akan bersifat subyektif atau berdasarkan intuisi belaka dan mengabaikan keputusan yang lain. (Tjiptono, 2002:4)

Strategi mengikat semua bagian perusahaan dan meliputi semua aspek penting perusahaan dengan menggunakan segenap sumber daya perusahaan secara efektif dalam lingkungan yang berubah-ubah dengan proses keserasian dan keseimbangan. Keputusan strategis mencakup batasan bisnis, produk dan pasar yang harus dilayani, tugas-tugas yang harus dilaksanakan dan kebijakan utama yang diperlukan. (Jauch dan Glueck, 1999:1213).

Menurut Hermawan Kartajaya, strategi yang mencakup segmentasi, targeting, dan positioning memiliki peranan kunci untuk memenangkan mind share. Segmentasi didefinisikan sebagai cara melihat pasar secara kreatif, karena itu segmentasi bisa disebut juga sebagai mapping strategy atau strategi dalam memetakan pasar. Setelah pasar di segmentasi ke dalam kelompokkelompok pelanggan potensial dengan karateristik dan perilaku serupa, pemasar kemudian harus bisa memilih segmen pasar mana yang akan dituju, aktivitas tersebut dinamakan targeting. ( Kartajaya, 2005:71) 


\section{B. Komunikasi Pemasaran}

Komunikasi memegang peranan penting bagi pemasar, karena tanpa komunikasi, konsumen maupun masyarakat secara keseluruhan tidak akan mengetahui keberadaan produk di pasaran. Komunikasi pemasaran membutuhkan anggaran yang tidak sedikit, oleh karena itu pemasar harus berhati-hati dan penuh perhitungan dalam menyusun rencana komunikasi pemasaran. Penentuan siapa saja sasaran komunikasi akan sangat menentukan keberhasilan komunikasi. Dengan penentuan sasaran yang tepat, proses komunikasi akan berjalan efektif dan efisien.

Intergated Marketing Communications (IMC) menurut Four As (the American Association of Advertising Agency) adalah konsep perencanaan komunikasi pemasaran yang mengakui nilai tambah rencana komprehensif yang mengkaji peran strategis dari masing-masing bentuk komunikasi, seperti iklan, direct marketing, promosi, serta public relation dan memadukannya untuk meraih kejelasan, konsistensi, dan dampak komunikasi secara maksimal melalui pengintegrasian maksimal. (Sulaksana, 2003:30)

Setiap metode pemasaran memiliki kekuatan dan kelemahan masing-masing dan akan melibatkan aktivitas dan membutuhkan jenis keahlian berbeda. (Cannon, 2008:72) Media komunikasi pemasaran meliputi:

(1) Iklan (Advertising)

Iklan dapat digunakan untuk membangun citra produk berjangka panjang. Menurut Reinald Kasali, iklan didefinisikan sebagai suatu pesan yang menawarkan suatu produk yang ditujukan kepada masyarakat lewat suatu media. Iklan lebih diarahkan untuk membujuk orang supaya membeli. (Kasali, 1995:19)
(2) Promosi penjualan

Promosi penjualan atau sales promotion yaitu kegiatan pemasaran yang memberikan nilai tambah atau intensif kepada tenaga penjualan, distributor, atau konsumen yang diharapkan dapat meningkatkan penjualan. (Morissan, 2010:25) Secara luas, promosi penjualan dapat didefinisikan sebagai bentuk persuasi langsung melalui penggunaan berbagai insentif, umumnya berjangka pendek, yang dapat diatur untuk merangsang pembelian produk dengan segera atau meningkatkan jumlah barang yang dibeli konsumen atau pedagang. (Sulaksana 2003:109)

(3) Acara dan Pengalaman

Acara dan pengalaman merupakan kegiatan dan program yang dirancang untuk menciptakan interaksi harian atau interaksi yang berhubungan dengan merek tertentu. (Kotler \& Keller, 2009:174) Merek dapat menciptakan lima jenis pengalaman yang berbeda-beda: indra, perasaan, pikiran, tindakan, kaitan. Menciptakan pengalaman sebagian besar pemasaran lokal dan akar rumput adalah pemasar pengalaman, yang tidak hanya mengkomunikasikan fitur dan manfaat, tetapi juga menghubungkan produk atau jasa dengan pengalaman unik dan menarik.

(4) Public relations dan Publisitas

Publisitas merupakan salah satu teknik yang sering digunakan dalam program public relations atau humas, yaitu kegiatan menempatkan berita mengenai seseorang, organisasi, atau perusahaan di media massa. Publisitas adalah suatu bentuk komunikasi non personal dalam bentuk berita (news story form), 
sehubungan dengan organisasi tertentu, dan atau tentang produkproduknya yang ditransmisi melalui perantara media massa. (Muhammad, 29:60)

(5) Direct marketing

Dengan berkembangnya sarana transportasi dan komunikasi maka kontak atau transaksi antara penjual dan pembeli menjadi lebih mudah. Direct marketing adalah sistem pemasaran interaktif yang memanfaatkan satu atau beberapa media iklan untuk menimbulkan respon yang terukur dan transaksi di sembarang lokasi. (Sulaksana, 2003:150) Komunikasi langsung antara antara seorang penjual dan konsumen selain menggunakan metode promosi adalah melalui penjualan personal tatap muka, sebagian besar komunikasi pemasaran langsung dirancang untuk mendapatkan umpan balik segera dari pelanggan. (Cannon, 2008:80)

\section{Strategi Komunikasi Pemasaran Terpadu}

Strategi komunikasi pemasaran terpadu ini terbagi menjadi tiga aktivitas utama yaitu perencanaan, pelaksanaan, dan evaluasi program komunikasi pemasaran terpadu. Berikut penjelasan dari masingmasing elemen aktivitas komunikasi pemasaran terpadu:

\section{a. Perencanaan Komunikasi Pemasaran Terpadu}

1) Menganalisis Situasi

Sebelum menentukan tujuan-tujuan pemasaran yang ingin dicapai, hendaknya peneliti melakukan analisis SWOT guna melihat sisi dari Strength (kekuatan perusahaan), Weakness (kelemahan perusahaan), Opportunity (peluang bisnis), dan Threath (hambatan untuk mencapai tujuan). (Siswanto, 2002:8).
2) Mengidentifikasi Khalayak Sasaran Khalayak sasaran akan sangat mempengaruhi keputusan-keputusan pemasar tentang apa yang akan disampaikan, kapan itu disampaikan, dimana itu disampaikan, dan siapa yang menyampaikan (Kotler \& Gary, 2004:610). Dalam mengidentifikasi khalayak sasaran diperlukan analisis segmentasi pasar, penentuan target sasaran, dan positioning produk, berikut penjelasan mengenai ketiga hal tersebut. (Kasali, 1998:388)
(a) Segmentasi pasar
(b) Penentuan target pasar
(c) Positioning produk

3) Menentukan Tujuan Komunikasi Pemasaran

Dalam hal komunikasi pemasaran, komunikasi bertujuan untuk membangkitkan keinginan pada konsumen untuk membeli produk. Tetapi pembelian adalah hasil dari proses panjang pembuatan keputusan konsumen. Komunikator pemasaran perlu mengetahui di posisi mana khalayak sasaran berada dan sampai tahap mana khalayak perlu digerakkan. (Kotler \& Gary, 2004:610) Penentuan tujuan komunikasi pemasaran terpadu adalah hal yang fundamental sebelum pelaksanaannya. Hal ini bertujuan untuk selalu menjaga konsistensi pelaksanaan komunikasi pemasaran agar selalu berada di dalam satu koridor dengan tujuan awal. (Kasali, 1998:116).

Setelah pasar sasaran dan persepsinya dipahami, komunikator pemasaran mesti merumuskan respon audiens yang diinginkan. Pemasar mungkin hanya ingin menempatkan pesannya dalam benak konsumen (kognitif), mengubah sikapnya (afektif), atau mendorongnya untuk 
berbuat sesuatu (perilaku). (Sulaksana, 2003:56)

4) Menetapkan

Anggaran

Komunikasi Pemasaran

Salah satu keputusan tersulit yang dihadapi oleh perusahaan adalah menentukan berapa banyak biaya yang harus dikeluarkan untuk kegiatan komunikasi pemasaran. Dalam memutuskan besarnya anggaran komunikasi pemasaran secara keseluruhan, terdapat empat metode umum yang dapat digunakan, yaitu: (Kotler \& Amstrong, 2001:125127)

(a) Metode yang terjangkau (affordability method)

(b) Metode presentase dari penjualan

(percentage-of-sales budgeting method)

(c) Metode paritas pesaing (competitive parity method)

(d) Metode tujuan-dan-tugas (objective-and-task method)

5) Pengembangan Program Komunikasi Pemasaran

Pengembangan program komunikasi pemasaran terpadu adalah langkah perencanaan komunikasi pemasaran yang paling berpengaruh. Tiap-tiap alat komunikasi pemasaran kelebihan dan kekurangan masing-masing. Dalam tahap ini, akan diputuskan alatalat komunikasi pemasaran apa saja yang akan digunakan, berdasarkan perannya masing-masing dan koordinasi antar elemen komunikasi pemasaran tersebut. (Belch, 2004:31) Adapun pengembangan program komunikasi pemasaran ini terdiri atas:

a) Merancang pesan

Dalam membentuk pesan yang konsisten, komunikator pemasaran harus merancang apa yang akan dikatakan (isi pesan) dan bagaimana mengatakan isi pesan tersebut (struktur dan format pesan). (Kotler \& Gary, 2004:613) Pesan harus menarik perhatian (attention), menimbulkan minat (interest), memicu keinginan (desire), dan mendorong orang untuk berbuat (desire). (Sulaksana, 2003:61)

b) Memilih media

Saluran komunikasi atau media dapat dibagi menjadi dua, yaitu: (1) Saluran Komunikasi Personal Saluran komunikasi personal meliputi dua orang atau lebih yang berkomunikasi secara tatap muka, pembicara dengan audiensnya. Komunikasi personal bisa lebih efektif karena adanya peluang untuk mengindividualisasikan penyampaian pesan dan umpan baliknya. (2) Saluran Komunikasi Non Personal Saluran komunikasi non personal adaalah media yang membawa pesan tanpa mengadakan kontak atau umpan balik pribadi. Saluran non personal meliputi media, atmosfir dan even. Media terdiri dari media cetak, media elektronik, dan media display (baliho, papan iklan, poster). Atmosfir adalah "lingkungan yang dikemas" yang dapat menciptakan atau memperkuat kecenderungan pembeli untuk membeli produk. Event merupakan peristiwa yang dirancang untuk mengkomunikasikan pesan tertentu pada audiens sasaran. Bagian Humas mengatur konferensi pers, peluncuran produk dan pensponsoran untuk merengkuh efek komunikasi khusus pada audiens. (Sulaksana, 2003:83)

c) Menelaah sifat masing-masing alat komunikasi pemasaran 
Setiap alat komunikasi pemasaran memiliki karakteristik dan biaya berbeda. Anggaran komunikasi pemasaran merupakan bagian dari anggaran pemasaran. Namun demikian tidak ada standar yang pasti mengenai seberapa besar pengeluaran untuk alat komunikasi pemasaran. (Sulaksana, 2003:164)

d) Menentukan strategi bauran komunikasi

pemasaran

Ada dua strategi dasar bauran komunikasi pemasaraan yang dapat di pilih oleh pemasar, yaitu: (1) Push Strategy, yaitu aktifitas promosi produsen kepada perantara (umumnya dengan penjualan personal dan trade promotion), dengan tujuan agar para perantara itu memesan, kemudian menjual, serta mempromosikan produk kepada konsumen akhir. (2) Full Strategy, yaitu aktifitas promosi produsen kepada konsumen akhir (biasanya dengan iklan dan consumer promotion), dengan tujuan agar mereka mencarinya pada para penyalur/perantara, yang pada gilirannya akan memesan produk tersebut kepada produsen. (Sulaksana, 2003:172)

e) Mengintegrasikan bauran komunikasi

pemasaran

Setelah menetapkan biaya dan bauran komunikasi pemasaran, perusahaan harus mengambil langkah-langkah untuk memastikan bahwa semua unsur bauran komunikasi pemasaran sudah terintegrasi dengan baik. (Gonring, 1994:45-48)

\section{b. Pelaksanaan Komunikasi Pemasaran Terpadu}

Pelaksanaan program Komunikasi pemasaran terpadu merupakan langkah yang melibatkan rincian dari proses perencanaan promosi, karena setiap elemen memiliki kelebihan dan keterbatasan/kelemahan tertentu. Tahapan-tahapan proses perencanaan dan pelaksanaan komunikasi pemasaran sebagaimana dijelaskan oleh Soemanegara, meliputi:

1) Pengkajian Perencanaan Pemasaran Sebelumnya

2) Pengembangan dan Perencanaan Kegiatan

3) Monitoring dan Analisa Situasi

4) Respon Konsumen

\section{c. Evaluasi Komunikasi Pemasaran Terpadu}

Setelah melakukan komunikasi pemasaran terpadu, komunikator harus meriset dampaknya pada khalayak sasaran. Tugas tersebut berupa upaya menanyakan kepada tiap-tiap khalayak sasaran apakah mereka mengingat pesan, berapa kali mereka melihat pesan, apa informasi utama yang mereka ingat, bagaimana perasaan mereka terhadap pesan tersebut, dan perubahan sikap dari masa lalu ke masa sekarang (setelah melihat pesan) terhadap produk perusahaan. Komunikator juga akan mengukur perilaku yang diakibatkan oleh pesan tersebut. (Kotler \& Gary, 2004:619)

\section{Wisatawan}

Kata wisatawan (tourist) merujuk pada orang. Secara umum wisatawan menjadi subset atau bagian dari traveller atau visitor. Untuk dapat disebut sebagai wisatawan, seseorang haruslah seorang traveller atau seorang visitor. (Pitana, 2009:35) 
Dalam kamus bahasa Inggris, orang yang melakukan perjalanan disebut traveller. Sedangkan orang yang melakukan perjalanan untuk tujuan wisata disebut tourist. Sedangkan di dalam undangundang Kepariwisataan Nomor 9 tahun 2000, wisatawan didefinisikan sebagai orang yang melakukan kegiatan wisata. Jadi menurut pengertian ini, semua orang yang melakukan perjalanan wisata disebut wisatawan apapun tujuannya dengan catatan perjalanan itu bukan untuk menetap dan tidak untuk mencari nafkah di tempat yang dikunjungi. (Damardjati, 2001:88)

Cohen (1972) mengklasifikasi wisatwan atas dasar tingkat familiarisasi dari daerah yang akan dikunjungi, serta tingkat pengorganisasian perjalanan wisatanya. Atas dasar ini, Cohen menggolongkan wisatawan menjadi empat, yaitu:

1) Drifter, yatiu wisatawan yang ingin mengunjungi daerah yang sama sekali belum diketahuinya, yang berpergian dalam jumlah kecil.

2) Explorer, yaitu wisatawan yang melakukan perjalanan dengan mengatur perjalanannya sendiri, tidak mau mengikuti jalan-jalan wisata yang yang sudah umum melainkan mencari hal yang tidak umum. Wisatawan seperti ini bersedia memanfaatkan fasilitas dengan standar lokal dan tingkat interaksinya dengan masyarakat lokal juga tinggi.

3) Individual Mass Tourist, yaitu wisatawan yang menyerahkan pengaturan perjalanannya kepada agen perjalanan, dan mengunjungi daerah tujuan wisata yang sudah terkenal.

4) Organized-Mass Tourist, yaitu wisatawan yang hanya mau mengunjungi daerah yang sudah dikenal, dengan fasilitas seperti yang dapat ditemuinya di tempat tinggalnya, dan perjalanannya selalu di pandu oleh pemandu wisata. (Pitana, 2009:47)

Jenis-Jenis Wisatawan:

(1) Wisatawan Asing (Foreign Tourist)

Orang asing yang melakukan perjalanan wisata, yang datang memasuki suatu negara lain yang bukan merupakan negara di mana ia biasanya tinggal. Wisatawan ini disebut juga wisatawan mancanegara.

(2) Domestic Foreign Tourist

Orang asing yang berdiam atau bertempat tinggal di suatu negara karena tugas, dan melakukan perjalanan wisata di wilayah di mana ia tinggal.

(3) Domestic Tourist

Seorang warga negara suatu negara yang melakukan perjalanan wisata daam batas wilayah negaranya sendiri tanpa melewati perbatasan negaranya. Wisatawan ini disebut juga wisatwan dalam negeri atau wisatawan nusantara (wisnu).

(4) Indigeneus Foreign Tourist

Warga negara suatu negara tertentu, yang karena tugasnya atau jabatannya berada di luar negeri, pulang ke negara asalnya dan melakukan perjalanan wisata di wilayah negaranya sendiri. Jenis wisatawan ini merupakan kebalikan dari Domestic Foreign Tourist.

(5) Transit Tourist

Wisatwan yang sedang melakukan perjalanan ke suatu negara tertentu, yang terpaksa mampir atau singgah pada suatu pelabuhan/airport/stasiun bukan atas kemauannya sendiri.

(6) Business Tourist

Orang yang melakukan perjalanan untuk tujuan bisnis, bukan wisata, tetapi perjalanan wisata akan 
dilakukannya setelah tujuannya yang utama selesai. Jadi, perjalanan wisata merupakan tujuan sekunder, setelah tujuan promer yaitu bisnis selesai dilakukan. (Karyono, 1997:2122)

\section{Motivasi Aktivitas Wisatawan:}

1) Motivasi Fisik

Tujuan wisatawan melakukan pariwisata adalah untuk memperoleh sesuatu yang berhubungan dengan hasrat untuk mengembalikan kondisi fisik, istirahat, santai, olah raga atau pemeliharaan kesehatan.

2) Motivasi Kultural

Tujuan wisatawan melakukan aktivitas pariwisata adalah ada kaitannya dengan keinginan pribadi sesorang yakni supaya dapat melihat dan mengetahui negara/daerah lain, terutama mengenai penduduk dan kebudayaannya.

3) Motivasi Interpersonal

Motivasi wisatawan melakukan aktivitas pariwisata adalah keinginan seseorang untuk mengunjungi sanak keluarga, teman baru, dan lain-lain. motivasi ini erat hubungannya dengan keinginan seseorang untuk melarikan diri dari kesibukan rutin sehari-hari.

4) Motivasi Status dan Harga Diri

Dalam hal ini motif yang mendorong wisatawan adalah suatu pamer, maksud dari perjalanannya adalah untuk memperlihatkan "siapa dia", yakni untuk menunjukkan kedudukannya, statusnya dalam masyarakat tertentu demi prestige pribadinya. (Baiquni, 2011:36)

\section{Metode Penelitian}

Metode yang digunakan dalam penelitian ini adalah metode penelitian kualitatif dengan menggunakan pendekatan analisis deskriptif. Menurut Creswell, proses penilaian kualitatif melibatkan upaya-upaya penting, seperti mengajukan pertanyaan-pertanyaan dan prosedur-prosedur, mengumpulkan data yang spesifik dari para partisipan, menganalisis data yang spesifik dari para partisipan, kemudian data dianalisis secara induktif mulai dari tema yang bersifat khusus ke tema yang bersifat umum, dan selanjutnya menafsirkan makna data. (Creswell, 2010:4)

Digunakannya metode penelitian kualitatif, karena penelitian ini hanya memaparkan situasi/ peristiwa dan tidak ditujukan mencari atau menjelaskan hubungan, tidak menguji hipotesis atau membuat prediksi. (Rahmat,2001:24)

Dalam penelitian ini, data yang diperoleh adalah berupa kata-kata, gambar. Data tersebut berasal dari naskah wawancara, catatan lapangan, foto, video tape, dokumen pribadi, catatan atau memo, dan dokumen resmi lainnya. (Moloeng, 1993:11)

Untuk menganalisis data penelitian, penulis menerapkan analisis deskriptif yang bertujuan untuk mendeskripsikan secara sistematis, faktual, dan akurat tentang fakta-fakta dan sifat-sifat objek tertentu. Melalui kerangka konseptual (landasan teori), peneliti melakukan operasionalisasi konsep yang akan menghasilkan variabel beserta indikatornya. Riset ini untuk menggambarkan realitas yang sedang terjadi tanpa menjelaskan hubungan antar variabel. (Kriyantono, 2007:69) Paradigma dari penelitian ini adalah konstruktivisme, dimana penelitian bertujuan untuk menilai perilaku manusia secara fundamental. Paradigma ini dipengaruhi oleh perspektif interaksi simbolis dan perspektif struktural fungsional. Perspektif interaksi simbolis ini mengatakan bahwa manusia secara aktif dan kreatif mengembangkan respons terhadap stimulus dalam dunia kognitifnya. (Bungin, 2008:69) 
Keberadaan peneliti menjadi bagian integral dari data, artinya peneliti ikut aktif dalam menentukan jenis data yang diinginkan. Dengan demikian, peneliti menjadi instrumen penelitian yang harus terjun langsung di lapangan.

1. Subyek penelitian adalah informan yaitu orang yang memberikan informasi tentang situasi dan kondisi dari latar penelitian. Informan penelitian ini ditentukan berdasarkan key person. (Bungin, 2007:77)

2. Objek Penelitian

Objek penelitian ini adalah Nagari Koto Hilalang di Kabupaten Solok, Provinsi Sumatera Barat

\section{Teknik Pengumpulan Data}

Dalam penelitian ini peneliti akan menggunakan metode wawancara, observasi, dan dokumentasi. (Bungin, 2007:108)

Metode pengumpulan data adalah teknik atau cara-cara yang dapat digunakan periset untuk mengumpulkan data. Ada beberapa teknik dan metode pengumpulan data yang biasanya dilakukan oleh peneliti. (Kriyantono, 2007:91)

Jenis data yang akan dieksplorasi oleh peneliti dilapangan, meliputi:

\section{1) Data Primer}

Data ini merupakan data yang dikumpulkan dari lapangan dengan melakukan depth interview kepada beberapa informan kunci dan pihakpihak yang terkait dengan perihal objek wisata Nagari Koto Hilalang mampu memberikan informasi yang dibutuhkan oleh peneliti.

2) Data Sekunder

Data ini merupakan data yang diperoleh dari studi kepustakaan atau buku literatur, publikasi nasional dan internasional, majalah, internet, dan lain-lain berkaitan informasi-informasi yang terkait dengan penelitian.
Pencarian data dilakukan dengan pertimbangan bahwa data-data tersebut dapat menjadi jembatan dari fakta dan realitas yang terjadi di lapangan sehingga diperoleh validitas dan pengetahuan yang lebih mengenai objek penelitian.

\section{Metode Analisis Data}

Berdasarkan pendapat Miles Hubernan, terdapat tiga jalur dalam menganalisis data kualitatif, yaitu reduksi data, penyajian data, dan penarikan kesimpulan. (Sutopo, 2002:96)

Setelah data diperoleh, kemudian dianalisis hingga menemukan deskripsi berkenaan tentang strategi promosi yang akan dilakukan guna menarik kunjungan wisatawan ke Nagari Koto Hilalang. Dalam penelitian deskriptif ini, metode yang digunakan adalah analisis model Milles dan Haberman (1994) yang dikenal dengan istilah interactive model. (Pawito, 2007:104)

\section{Uji Keabsahan Data}

Untuk menjaga keabsahan data penelitian, peneliti melakukan teknik triagulasi data, yaitu menganalisis jawaban subjek dengan meneliti kebenarannya dengan data empiris (sumber data lainnya) yang tersedia. Di sini jawaban subjek di cross-check dengan dokumen yang ada. (Kriyantono, 2007:70)

\section{Penyajian Data}

Penyajian data (data display) adalah kegiatan ketika sekumpulan informasi disusun, dicatat sehingga memberi kemungkinan akan adanya penarikan kesimpulan dan pengambilan tindakan. Bentuk penyajian data kualitatif meliputi pembuatan: 1) teks naratif: berbentuk catatan lapangan, 2) matriks, grafik, jaringan, dan bagan. 


\section{Hasil dan Pembahasan}

\section{Strategi Perencanaan Konsep Komunikasi Pemasaran Desa Wisata}

Dalam menyusun rencana strategi komunikasi pemasaran wisata Nagari Koto Hilalang bertolak dari hasil analisis lapangan yang dilakukan peneliti sebelumnya di lapangan, antara lain menganalisa kondisi fisik, analisa potensi kawasan wisata, analisa kebutuhan sarana dan prasarana, analisa atraksi wisata, dan analisa pangsa pasar.

1. Fisik

Analisa fisik kawasan di Nagari Koto Hilalang dilakukan dengan melihat guna lahan dominan dan bentuk morfologi Nagari Koto Hilalang. Berdasarkan jenis guna lahannya, Nagari Koto Hilalang didominasi oleh hutan dan kebun campuran. Nagari Koto Hilalang berada di daerah perbukitan dan bergelombang. Karena berada di ketinggian Nagari Koto Hilalang memiliki pemandangan alam yang bagus dan menarik, sehingga dapat dijadikan daya tarik wisata.

2. Potensi Kawasan Wisata

Analisa potensi kawasan wisata Nagari Koto Hilalang dilakukan dengan melihat potensi daya tarik wisata dan keunikan rumah gadang. Potensi daya tarik wisata di Nagari Koto Hilalang setalah di analisis dapat dibagi menjadi dua yaitu potensi fisik dan potensi budaya. Potensi fisik dilihat dari kondisi alam Nagari Koto Hilalang yang memiliki pemandangan yang menarik. Sedangkan potensi budaya Nagari Koto Hilalang dapat dilihat dari rumah gadang yang tersebar, tradisi atau kesenian, dan makanan tradisional. Potensi kawasan wisata tidak hanya dilihat dari potensi wisata tetapi juga dilihat dari keunikan yang ada di Nagari Koto Hilalang yaitu sebaran rumah gadang. Rumah gadang ini setelah dikelompokkan memiliki keunikan baik dari segi kepemilikan, bentuk, jumlah ruang dan jenis ukiran. Dari hasil analisis potensi kawasan wisata di Nagari Koto Hilalang ini dapat dikatakan bahwa Nagari Koto Hilalang memiliki potensi wisata yang dapat dikembangkan.

3. Pangsa Pasar

Dalam menganalisis pangsa pasar dilakukan dengan cara melihat pangsa pasar yang sesuai dengan jenis wisata di Nagari Koto Hilalang. Berdasarkan hasil analisa, diperkirakan pangsa pasar yang sesuai dengan wisata Nagari Koto Hilalang ini adalah wisata minat khusus. Wisata minat khusus ini merupakan bentuk kegiatan wisatawan berkelompok, individu atau rombongan dengam memberikan pengalaman baru, wisata sosial dan pendidikan.

4. Sarana Prasarana

Sebagai kawasan wisata daerah, Nagari Koto Hilalang membutuhkan perbaikan infrastruktur, pengadaan sarana dan prasarana pendukung pariwisata. Berdasarkan hasil analisa kebutuhan sarana dan prasarana pendukung pariwisata, Nagari Koto Hilalang belum memiliki tempat penginapan/ guest house, tempat makan/ restoran, toko souvenir, papan informasi, pintu gerbang dan lain-lain. Oleh sebab itu, kebutuhan sarana dan parasana perlu dalam pengembangan konsep dan rencana Nagari Koto Hilalang nantinya.

\section{Konsep Pengembangan Objek Wisata}

Pengembangan objek wisata adalah pengembangan objek dan daya tarik wisata, akomodasi, transportasi wisata, pelayanan wisata dan pemasaran wisata 
untuk selalu mempertahankan agar objek wisata tersebut mempunyai daya tarik bagi orang untuk mengunjungi suatu daerah tertentu.

Program pengembangan pariwisata dilakukan dengan mendayagunakan potensi sumber daya alam, seni dan budaya. Pengembangan sumber daya tersebut dapat dikelola melalui pendekatan peningkatan nilai tambah sumber daya secara terpadu antara pengembangan produk wisata dan pengembangan pemasaran pariwisata melalui pendekatan pemberdayaaan masyarakat lokal dalam rangka pengembangan pariwisata.

\section{Rencana Pengembangan Objek Wisata yang Diusulkan}

Rencana pengembangan pariwisata yang diusulkan di Nagari Koto Hilalang berupa pengembangan atraksi wisata alam dan budaya yang ditawarkan dalam bentuk paket wisata. Rencana pengembangan pariwisata ini didasarkan atas potensi wisata yang ada di Nagari Koto Hilalang di sesuaikan dengan zona-zona yang direncanakan.

\section{Rencana Strategi Komunikasi Pemasaran Wisata}

Dalam penyusunan strategi pemasaran wisata, peneliti hanya sebatas membuat planning bersama. Hal tersebut dikarenakan dalam pelaksanaannya membutuhkan biaya yang tidak sedikit. Usulan tema dari strategi komunikasi pemasaran disesuaikan dengan konsep tema pengembangan desa wisata, yaitu: "Mewujudkan Nagari Tradisional Koto Hilalang Sebagai Kawasan Wisata Budaya dan Kehidupan Tradisional ", tema tersebut diambil dengan tujuan agar para wisatawan tertarik untuk lebih mengenal nilai-nilai kebudayaan dan kearifan lokal yang ada, selain untuk melihat heritage berupa rumah gadang yang tersebar di Nagari Koto Hilalang.

Untuk pelaksanaan dari usulan strategi komunikasi pemasaran ini, nantinya akan melibatkan banyak sektor industri kreatif , meliputi:

1) Kelompok Industri Publikasi dan Presentasi Melalui Media (Media Publishing and Presence). Kelompok ini terdiri dari; Penerbitan \& Percetakan dan Periklanan.

2) Kelompok Industri dengan Kandungan Budaya yang Disampaikan Melalui Media Elektronik (Electronic Media Presentation with Cultural Content). Kelompok ini terdiri dari; TV \& Radio dan Film, Video, \& Fotografi.

3) Kelompok Industri dengan Kandungan Budaya yang Ditampilkan ke Publik baik secara langsung maupun lewat media elektronik (Cultural Presentation). Kelompok ini terdiri dari; Musik dan Seni Pertunjukan.

4) Kelompok Industri yang Padat Kandungan Seni dan Budaya (Arts and Culture Intensive). Kelompok ini terdiri dari; Kerajinan dan Pasar Barang Seni.

5) Kelompok Industri Desain. Kelompok ini terdiri dari; Desain, Fesyen, dan Arsitektur.

6) Kelompok Industri Kreatif dengan Muatan Teknologi (Creativity with Technology). Kelompok ini terdiri dari; Riset \& Pengembangan, Permainan Interaktif, dan Teknologi Informasi \& Jasa Perangkat Lunak. 
Tabel Strategi Komunikasi Pemasaran Wisata Nagari Koto Hilalang

\begin{tabular}{|c|c|c|c|}
\hline Analisa Lapangan & Konsep Pengembangan Objek Wisata & $\begin{array}{c}\text { Rencana } \\
\text { Pengembang } \\
\text { an yg } \\
\text { diusulkan }\end{array}$ & $\begin{array}{c}\text { Rencana Strategi Pemasaran } \\
\text { wisata }\end{array}$ \\
\hline $\begin{array}{l}\text { 1. Kondisi Fisik: } \\
\text { - Hutan } \\
\text { - Kebun campuran } \\
\text { - Perbukitan } \\
\text { 2. Potensi Atraksi: } \\
\text { a. Potensi fisik } \\
\text { - Kondisi alam } \\
\text { b.Potensi budaya: } \\
\text { - keunikan rumah gadang } \\
\text { - tradisi dan kesenian } \\
\text { - makanan tradisional } \\
\text { 3. Kebutuhan sarana \& prasarana: } \\
\text { - Perbaikan Infrastruktur } \\
\text { - Penyediaan sarana transportasi } \\
\text { - Penginapan } \\
\text { - Rumah makan } \\
\text { - Toko Suvenir } \\
\text { - Papan Informasi } \\
\text { - Gapura/ Pintu gerbang } \\
\text { 4. Pangsa Pasar } \\
\text { - Wisatawan } \\
\text { kelompok } \\
\text { - Wisatawan } \\
\text { - Werorangan } \\
\text { rombongan }\end{array}$ & $\begin{array}{l}\text { 1.Pengembangan } \\
\text { Wisata } \\
\text { - Atraksi Wisata } \\
\text { - Akomodasi } \\
\text { - Transportasi } \\
\text { - Pelayanan } \\
\text { wisata } \\
\text { - Pemasaran } \\
\text { Wisata } \\
\text { 2.Program Pengembangan } \\
\text { - Mendayaguna } \\
\text { kan potensi wisata alam, seni dan budaya } \\
\text { - Peningkatan nilai tambah sumber daya } \\
\text { - Pemberdayaan masyarakat lokal }\end{array}$ & $\begin{array}{l}\text { Membuat } \\
\text { Paket } \\
\text { Wisata }\end{array}$ & $\begin{array}{l}\text { 1. Konsep dari tema pemasaran } \\
\text { Desa Wisata, “Mewujudkan } \\
\text { Nagari Tradisional Koto } \\
\text { Hilalang sebagai Kawasan } \\
\text { Wisata Budaya dan } \\
\text { Kehidupan Tradisional” } \\
\text { 2. Pelibatan berbagai sector } \\
\text { industry kreatif sebagai media } \\
\text { pemasaran, meliputi: } \\
\text { - Penerbitan, percetakan \& } \\
\text { advertising } \\
\text { - Mass media elektronik } \\
\text { - Kelompok Seni \& musik } \\
\text { - Kelompok industry kerajinan } \\
\text { \& pasar barang seni } \\
\text { - Designer fesyen \& arsitektur } \\
\text { - Kelompok Litbang, TI, dsb }\end{array}$ \\
\hline
\end{tabular}

\section{Kesimpulan}

Hasil temuan di lapangan berdasarkan analisa yang sudah dilakukan sebelumnya, menunjukan jika kegiatan kehidupan masyarakat sehari-hari dan rumah tradisional Minang menjadi ciri khas di Nagari Koto Hilalang. Kondisi tersebut sangat berpotensi untuk dikembangkannya Nagari Koto Hilalang menjadi kawasan desa wisata yang berbasis agro dan budaya. Konsep pengembangan secara spasial terbagi menjadi tiga, yaitu menyediakan rute perjalanan wisata guna mengelilingi kawasan desa wisata, mengupayakan tersedianya sarana transportasi khusus untuk menuju dan berkeliling desa wisata serta menyediakan fasilitas pendukung dan penunjang kegiatan wisata lainnya.
Sedangkan konsep pengembangan non spasial yang harus dilakukan untuk mengembangkan kawasan desa wisata di Nagari Koto Hilalang agar dapat berkembang antara lain:

1. Melibatkan pemerintah daerah, tokoh masyarakat adat dan masyarakat adat setempat dalam proses pengembangan kawasan desa wisata.

2. Menyusun konsep pelatihan sumber daya manusia setempat guna menambah wawasan tentang pariwisata, cara memperlakukan wisatawan, termasuk pelatihan bahasa Inggris.

3. Membuat konsep strategi komunikasi pemasaran kawasan desa wisata, prioritas utama membuat web yang terhubung langsung dengan web Kabupaten 
Solok dan bekerja sama dengan berbagai media promosi.

4. Mengusulkan keseluruhan konsepkonsep yang tersusun berdasarkan hasil musyawarah bersama sebagai dasar pengembangan kawasan desa wisata oleh pemerintah daerah.

\section{Daftar Pustaka:}

Adisaputro, Gunawan. 2010. Manajemen pemasaran: Analisis untuk Perancangan Strategi Pemasaran. Yogyakarta: Sekolah Tinggi Ilmu Manajemen YKPN.

Baiquni, M dan Wardiyanto. 2011. Perencanaan dan Pengembangan Pariwisata. Bandung: CV Lubuk Agung.

Belch, George E. 2004. Advertising \& Promotion: An Integrated Marketing Communication Perspective/George E. Belch; Michael A. Belch. New York: McGraw Hill.

Bungin, Burhan. 2007. Penelitian Kualitatif: Komunikasi, Ekonomi, Kebijakan Publik, dan Ilmu Sosial Lainnya. Jakarta: Kencana

Cannon, Joseph P. 2008. Pemasaran Pasar: Pendekatan Manajerial Global = Basic Marketing: A Global Managerial Approach. Jakarta: Salemba.

Creswell, John W. 2010. Reserarch Design: Pendekatan Kualitatif, Kuantitatif, dan Mixed. Yogyakarta: Pustaka Pelajar.

Damardjati, RS. 2001. Istilah-istilah Dunia Pariwisata (cetakan keenam). Jakarta: Pradnya Paramita.

Gonring, Matthew. 1994. Putting Integrted Marketing Communication to Work Today. Fall, Public Relations Quartely.

Jauch, Lawrence R. \& Glueck, William F. 1999. Manajemen Strategis dan Kebijakan Bersaing, terjemahan Agus Dharma. Jakarta: Penerbit Erlangga.

Karyono, Hari. 1997. Kepariwisataan. Jakarta: PT Grafindo.

Kasali, Rhenald. 1995. Manajemen Periklanan. Jakarta: PT Grafiti.
. 1998. Membidik Pasar Indonesia: Segmentasi, Targeting, Positioning. Jakarta: PT Gramedia.

Kartajaya, Hermawan. 2005. Attracting Tourists Taraders Investors. Strategi Memasarkan Daerah di Era Otonomi. Jakarta: PT. Gramedia Pustaka Utama

Kotler, Philip dan Keller, Kevin Lane. 2009. Manajemen Pemasaran jilid 2. Jakarta: Erlangga.

Kotler, Philip dan Amstrong, Gary. 2001. Prinsip-prinsip Pemasaran Jilid 2. (Damos Sihombing. Alih Bahasa). Jakarta: Erlangga.

. 2004. Dasar-dasar Pemasaran Jilid

2. Jakarta: Indeks.

Kriyantono, Rachmat. 2007. Riset Komunikasi. Jakarta: Kencana.

Morissan. 2010. Periklanan: Komunikasi Pemasaran Terpadu. Jakarta: Kencana.

. 2010. Teori Komunikasi Massa: Media, Budaya dan Masyarakat. Bogor: Ghalia Indonesia.

Maloeng, Lexi J. 1993. Metode Penelitian Kualitatif. Bandung: Remaja Rosdakarya.

Sutopo, H.B. 2002. Metodologi Penelitian Kualitatif - Dasar Teori dan Terapannya dalam Penelitian. Sebelas Maret University Press: Surakarta.

Muhammad, As'adi. 2009. Cara Pintar Promosi Murah dan Efektif. Yogyakarta: Garailmu.

Pitana, I G. dan I Ketut Surya Diarta. 2009. Pengantar Ilmu Pariwisata. Yogyakarta: Andi.

Pawito. 2007. Metode Penelitian Kualitatif. Yogyakarta: L-kis.

Siswanto dan Kleinsteuber, Freitz. 2002. Strategi Manajemen Pemasaran. Jakarata: Damar Melia Pustaka.

Soemanegara, Rd. 2006. Strategic Marketing Communication-Konsep Strategis dan Terapan. Bandung: Alfabeta. 
Sulaksana, Uyung. 2003. Integrated Marketing Communication.

Yogyakarta: Putaka Pelajar.

Tjiptono, Fandy. 2002. Strategi Pemasaran. Yogyakarta: Andi. 